\title{
Examining the relevance of cultural ecosystem services in forest management in Europe
}

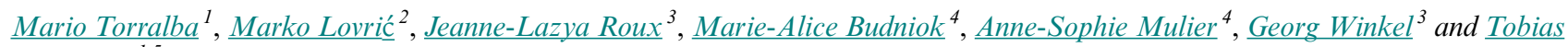 \\ $\underline{\text { Plieninger }}^{1,5}$
}

\begin{abstract}
The ecosystem services framework has become one of the most important paradigms in forest planning and management as a way to link the multiple provisioning, regulating, and cultural services derived from ecosystems and their benefits to human wellbeing. Recently, there have been multiple efforts in emphasizing the importance of cultural ecosystem services (CES). However, the consideration of CES in management models remains a challenge. In the current context of increased demand for the joint supply of multiple ecosystem services, we aim to evaluate which CES are currently promoted by European landowners, what their the future could be, and which factors support or hinder these processes. Our findings are based on a survey of 1182 forest landowners from 25 European countries. By using a mixed-method approach that combines descriptive, ordination, and cluster analysis with qualitative data, our results reveal that CES are currently of high relevance in European forests and forest owners and managers have a generally positive attitude toward further promotion of CES through forest management. There is a high degree of synergy between CES, which suggests that many of them could be jointly promoted. Our analysis further identifies the existence of four differentiated types of forest owners based on their attitudes and management in relation to CES. These groups also differ in regard to the challenges and barriers they perceive in relation to forest CES. These diverse perspectives among Europe's landowners suggest the need for different strategies that satisfy the diverse context-related social-ecological needs required to further promote CES in European forests.
\end{abstract}

Key Words: ecosystem service trade-offs; multifunctionality; forest owners and managers

\section{INTRODUCTION}

Forests provide multiple ecosystem services such as timber, carbon sequestration, hydrological regulation, and recreation (MEA 2005). A strong focus on one single service, for example, on timber production, typically tends to cause trade-offs with other ecosystem services and generates a negative impact on some of them, like reducing biodiversity levels (Duncker et al. 2012). In contrast, a management that enhances the multifunctionality of the forest, i.e., by promoting the structural heterogeneity and increasing accessibility of forests, tends to create synergies and promote multiple ecosystem services simultaneously, at the cost of reducing timber production from its maximum potential (Felipe-Lucia et al. 2018).

References to the multiple values forests entail for society (including but also beyond timber) go back far into the history of discussions about sustainable forest management (Von Carlowitz 1732), and the many ecosystem services forests provide have been a topic in both research and policy making already in the 19th century in Europe (Pistorius et al. 2012). Scientific/ professional forestry that evolved at that time was, however, also criticized for sidelining some ecosystem services in seeking efficiency and sustainable timber supply (Scott 1998, Winkel 2012). Partly in relation to this critique, but also in response to the increasing social demand for multiple forest ecosystem services and the development of landscape approaches (Bieling 2004, Plieninger et al. 2015), the last decades have seen the development of various forest management concepts emphasizing the importance of multiple functions or ecosystem services. These would include concepts such as multifunctional or multiuse forestry (Hall 1963, Borrass et al. 2017, HoogstraKlein et al. 2017), retention forestry (Gustafsson et al. 2020), or integrated forest management (Kraus and Krumm 2013, Maier and Winkel 2017, Sotirov and Arts 2018).

Forest owners and managers (collectively referred to as forest operators hereafter) play a key role in the supply of forest ecosystem services because they are the main decision makers regarding forest planning and management. Their management will impact the structure and composition of the forest, determining their capacity to deliver multiple ecosystem services (Schaich and Plieninger 2013, Rendenieks et al. 2015). What management decisions they make depends on several factors. These decisions are largely rooted in personal values and perspectives, which go beyond economic profit and combine several other aspects like personal preferences, past experiences, cultural identities, and social norms (Hugosson and Ingemarson 2004, Urquhart et al. 2012, Maier and Winkel 2017, Torralba et al. 2018). When engaged, local forest operators have proof of their potential as capable forest stewards, contributing to the sustainable and multifunctional management of forests (PorterBolland et al. 2012, Estrada-Carmona et al. 2014, IMFN 2020).

In Europe, the situation of forest operators is very heterogeneous. In relation to land tenure, approximately half of the European forest surface belongs to private forest owners (Hirsch and Schmizhüsen 2010). However, there are countries where private ownership is predominant (i.e., France, Finland, or Austria), countries where private and public ownership are balanced (i.e., Belgium, Germany, or Latvia), and countries where public land

${ }^{1}$ Faculty of Organic Agricultural Sciences, University of Kassel, Witzenhausen, Germany, ${ }^{2}$ European Forest Institute, Bioeconomy Programme, Joensuu Office, Finland, ${ }^{3}$ European Forest Institute, Governance Programme, Bonn Office, Germany, ${ }^{4}$ European Landowners' Organization, Brussels, Belgium, ${ }^{5}$ Department of Agricultural Economics and Rural Development, University of Göttingen, Germany 
is predominant (i.e., Sweden, Czech Republic, or Bulgaria). Further differences exist in relation to the socio-demographic characteristics of forest operators, the size of their properties, and their level of organization (Hirsch and Schmizhüsen 2010, Pulla et al. 2013). From a policy perspective, this complex landscape needs to be carefully considered for designing policies and instruments focused on promoting a multifunctional management of the forest.

Although the need to provide multiple forest ecosystem services or functions is frequently underlined in European forest policy documents, as in the EU forest strategy (EC 2006), there is a continuous debate in how far such political ambitions are translated into instruments that promote forest management for multiple services (Winkel and Sotirov 2016, Borrass et al. 2017). This holds particularly true for cultural ecosystem services (CES), the nonmaterial benefits society obtains from ecosystems, which lag behind in both practical support and policy mechanisms in relation to other ecosystem services. Although forest ecosystem services have been integrated in forest related policies (such as the EU Biodiversity Strategy, EU Forest Strategy, Common Agricultural Policy, and the Green Infrastructure Strategy), specific references to CES at the EU level are only made in the Rural Development Regulation (EC 2013) and in the EU Forest Action Plan (EC 2006), and this recognition is restricted to the context of tourism and recreation.

There are several reasons for the lack of policy support mechanisms at the EU level regarding CES. First, competencies in the various policy sectors are differently shared and distributed between the EU and member states. Forestry is the responsibility of the member states while other important associated sectors, like water, are shared between EU and the states (Schleyer et al. 2015, Bouwma et al. 2018). Determining which governance level has the responsibility to develop policies on CES in forests is not an easy task, especially regarding CES such as recreational hunting. Second, CES are mostly referred to in an environmental context, which fuels the power asymmetries between economicoriented policy stakeholders, who might resist the adoption and mainstreaming in policy documents of concepts coming from environmental-oriented policy stakeholders (Turnpenny et al. 2014, Bouwma et al. 2018).

At a national level, in Europe the main focus falls on recreation, tourism, harvesting of wild products (particularly mushrooms and berries), hunting, and cultural/historical heritage (Appendix 1). It should also be kept in mind that in the EU, forest policy competence does not only lie at the national level, but often also at the subnational or regional level, as is the case with Austria, Belgium, Germany, Italy, Spain, and the UK (Lazdinis et al. 2019). Although there are several legislative policy mechanisms addressing CES, economic incentives for landowners to promote cultural values of forests do not yet exist. Most economic support is directed to timber production, and payments for ecosystem services usually target regulating services such as water services, biodiversity, or carbon sequestration (Wunder et al. 2019). In Finland, recreational benefits appeared as a spin-off of payments for ecosystem services schemes directed at biodiversity in the Forest Biodiversity Programme for Southern Finland because research has shown that the public appreciated mature forests with little signs of forests management (Mäntymaa et al. 2018).
The reasons for the spare references to CES in policies also relate to theoretical, practical, and methodological challenges intrinsic to CES quantification, valuation, and integration in long-term management plans (Chan et al. 2012, Satz et al. 2013). CES are inherently subjective (they mean something different for different groups of people), pluralistic (the importance of a given CES varies in different value-domains), interdependent (they inextricably influence each other), and in many cases lack a proper framework for a monetary economic translation. CES are intimately linked to regulating and provisioning ES, and emerge from the context-related interactions between the individual and/ or the group, and the ecosystem (Chan et al. 2016).

Demand for CES is strongly on the rise in Europe as a direct consequence of processes like urbanization, changes in lifestyle, and increase of environmental awareness, both from forest operators and society (Kanowski and Williams 2009, Satz et al. 2013, Cáceres et al. 2015, Wolff et al. 2015). This creates an opportunity to increase political support and societal appreciation of forests, while opening the window for innovation in the promotion and use of CES in forests. On the other hand, sophisticated promotion of CES in forests can also generate conflicts in relation to the use of the forest, particularly when these innovation processes leave key groups behind (Tyrväinen et al. 2017). Currently, very little is known about the uses of and management for CES in privately owned forests of Europe beyond some local and regional-level studies (i.e., Urquhart et al. 2012, Hendee and Flint 2014). Similarly, there are few public support programs that target promotion of CES in forests, and these are focused on those services that are easy to assess and consider market-based instruments such as recreation or aesthetic appreciation (Satz et al. 2013, Cooper et al. 2016).

In this context, we performed a Europe-wide survey targeting forest owners and managers with the following objectives:

1. To provide an overview of the current state and potential role of CES in European forests.

2. To assess synergies and trade-offs as perceived by forest operators in relation to CES.

3. To identify the different groups of forest operators in relation to their attitudes toward CES.

4. To uncover the barriers and limitations that hinder CES in Europe, and to identify potential pathways and strategies to overcome them.

\section{METHODS}

\section{Survey design and data collection}

Our survey included 16 questions that explored diverse factors related to forest management and CES (Appendix 2). The survey elicited which CES are currently relevant in the forest (by asking which activities providing nonmaterial benefits usually take place in the property) and which CES could potentially be further promoted in the forest (by asking which activities providing nonmaterial benefits could potentially take place on the property), given the appropriate context. Our understanding of CES was inclusive, considering a plurality of values that are associated with the relationships between individuals/groups and 
the ecosystem (Pascual et al. 2017). Thus, our classification of CES departed from the Millennium Ecosystem Assessment (MEA 2005), but went on to cover a broad range of activities associated with forest, including, i.e., beekeeping, which is directly associated with pollination, but is additionally related to nonmaterial benefits such as cultural identity, spirituality, or recreation (Hill et al. 2019). Because the survey was focused on forest operators' perspectives, it could only capture the activities that different users carry out in the forest, but not the specific nonmaterial benefits derived from them. As such, the final list of CES considered in the survey was the result of a series of deliberate discussions around which activities related to CES take place in European forests (Table 1), but do not cover some relevant CES derived from the nonuse of the landscape (like existence value).

The survey was available in 20 languages (Bulgarian, Croatian, Czech, Dutch, English, Estonian, Finnish, French, German, Hungarian, Italian, Latvian, Lithuanian, Polish, Portuguese, Romanian, Slovak, Slovenian, Spanish, and Swedish), and was translated and distributed through different forest owners' and managers' associations working at the EU level: the European Landowners' Organization (ELO), Copa-Cogeca, the Confederation of European Forest Owners (CEPF), the European Federation for Hunting and Conservation (FACE), the International Council for Game and Wildlife Conservation (CIC), and the European Historic Houses Association (EHHA). The specific formulations and categories provided in the survey were in some cases adapted in a preliminary iterative process to match the specific languagecontext of the different countries. The survey was distributed online between November 2017 and February 2018 by email and social media via national contact points, targeting all members of those organizations owning or managing forests.

The number of survey responses received was 1322. However, responses of participants not owning or managing forest land in Europe were not included in the analysis, which led to a reduction of the sample. Eventually, 1186 questionnaires were included in the analysis, including many properties that combined forests with patches of other land uses (grasslands, croplands, water bodies, etc.). All answers were translated by ELO and coded by the first two authors. Table 1 shows the main variables analyzed and the corresponding questions in the survey questions.

\section{Data processing and analysis}

We adopted a mixed-method analytical approach to assess and analyze the data collected in the survey. In a first analytical step, we used descriptive statistics to provide a general overview of the current state of CES in Europe for each of the variables assessed in the survey: socio-demographic information, integration of CES in management plans, existing facilities and management actions supporting CES, diversity of habitats, and current and potential CES in the forest.

A qualitative approach was used to assess the costs and barriers for further CES implementation, and the demands for policy support in relation to further CES promotion. Inductive coding was used to establish different categories for the two open questions. Coding was split between the two first authors in two separate coding rounds. The process led, through a series of deliberative discussions, to the establishment of five categories of costs and barriers, and eight types of policy measures for the promotion of CES promotion (Table 1). This qualitative data was used in the following analytical steps to augment and aid in the interpretation of the results, nuance the typology of forest operators, and outline the potential strategies to engage each type of forest owner.

In a second step, we assessed how the different CES relate to each other in relation to current and potential supply. This analysis allowed us to see which CES tend to enter into conflict with each other (trade-offs) and which ones tend to co-occur (synergies). To do so, we performed two principal component analyses (PCA). One PCA was done for the current CES in the forest, and one for the potential CES that could be incorporated. We used as input data the current and potential presence/absence of each of the CES categories (Table 1).

In a third analytical step, we performed a hierarchical cluster analysis (HCA) to identify whether there exist or not different groups of forest operators in relation to their management and attitudes toward CES. To do so, we used as input data the explicative factors (eigenvalue $>1$ ) from the two PCAs (five factors from the PCA on current use of CES and the two factors extracted from the PCA on potential future CES use) as clustering variables. To build the clusters we used the Euclidean distance and Ward linkage method in order to maximize the separation of each new cluster while minimizing the inner dispersion in each cluster (Ward 1963).

In a fourth analytical step, we characterized the identified groups in the cluster analysis. To do so, we performed a Kruskal-Wallis test, which assessed the differences between the different groups of forest operators in relation to: total number of current and potential CES, types and amount of facilities, supporting management actions, level of integration of CES in management, diversity of habitats, age, gender, and country of origin (for this last variable, for representativeness reasons we only included those countries with large representation in the dataset). We selected the Kruskal-Wallis test because of the dataset's internal heterogeneity and lack of normal distribution within the different groups of forest operators. All statistical analysis were made using the software Xlstats (Addinsoft 2009).

\section{RESULTS}

Overview and current state of CES in European forests

The 1186 responses of the dataset were distributed across 28 European countries. However, the response rate was geographically uneven, with approximately $80 \%$ of the responses concentrated in eight countries: France, Germany, Finland, Estonia, Sweden, Austria, Latvia, and Portugal (Fig. 1). The respondents were mostly men $(82.2 \%)$, between 51 and $70(49.3 \%)$ or 31 and 50 years $(31.3 \%$; Fig. 1$)$. The age and gender distribution in the dataset mirrored the heterogeneous characteristics of forest operators in Europe (Hirsch and Schmizhüsen 2010, Pulla et al. 2013). In relation to the different habitats present in the property, our results showed that several properties combined forests with patches of grasslands or croplands, and to a lesser extent with different types of water bodies (Fig. 1).

Around $40 \%$ of the respondents stated that CES are to some extent integrated in their management plans (Fig. 1). On average, 
Table 1. Variables and categories analyzed from the survey. CES = cultural ecosystem services.

\begin{tabular}{|c|c|c|c|}
\hline Variable & Original question & Type of question & Categories \\
\hline Current CES & $\begin{array}{l}\text { Which of these activities } \\
\text { currently take place on the } \\
\text { land/site(s) you manage? }\end{array}$ & $\begin{array}{l}\text { Multiple choice (multiple } \\
\text { answers permitted) }\end{array}$ & $\begin{array}{l}\text { Beekeeping } \\
\text { Hunting } \\
\text { Recreational fishing } \\
\text { Wild products harvesting } \\
\text { Provision of accommodation } \\
\text { Sports / Exercise } \\
\text { Dog walking } \\
\text { Horseback riding } \\
\text { Bird / Nature watching } \\
\text { Aesthetic experiences } \\
\text { Artistic activities } \\
\text { Spiritual enrichment } \\
\text { Cultural / Historical sites } \\
\text { Outdoor education } \\
\text { Research } \\
\text { Farming }\end{array}$ \\
\hline Potential CES & $\begin{array}{l}\text { Could the site/area that you } \\
\text { manage deliver any more of } \\
\text { these activities if you } \\
\text { received additional } \\
\text { incentives? }\end{array}$ & $\begin{array}{l}\text { Multiple choice (multiple } \\
\text { answers permitted) }\end{array}$ & \\
\hline $\begin{array}{l}\text { Existing facilities and } \\
\text { infrastructure that promote } \\
\text { CES supply }\end{array}$ & $\begin{array}{l}\text { What infrastructure is in } \\
\text { place in your land/site(s)? }\end{array}$ & $\begin{array}{l}\text { Multiple choice (multiple } \\
\text { answers permitted) }\end{array}$ & $\begin{array}{l}\text { Presence of access roads } \\
\text { Presence of trails and paths } \\
\text { Presence of toilets } \\
\text { Presence of parking facilities } \\
\text { Presence of walkways/bridges } \\
\text { Presence of signage } \\
\text { Designated area for accommodation }\end{array}$ \\
\hline $\begin{array}{l}\text { Management actions } \\
\text { supporting CES supply }\end{array}$ & $\begin{array}{l}\text { What types of actions do you } \\
\text { put in place to support CES } \\
\text { on your land/site(s)? }\end{array}$ & $\begin{array}{l}\text { Multiple choice (multiple } \\
\text { answers permitted) }\end{array}$ & $\begin{array}{l}\text { Road/trail maintenance } \\
\text { Additional garbage disposals } \\
\text { Control of invasive species } \\
\text { Outdoor learning programs } \\
\text { Adaptation of management practices } \\
\text { Habitat management }\end{array}$ \\
\hline $\begin{array}{l}\text { Habitats present on the } \\
\text { property in addition to } \\
\text { forests }\end{array}$ & $\begin{array}{l}\text { Please describe the types of } \\
\text { habitats/features present on } \\
\text { the land which you manage }\end{array}$ & $\begin{array}{l}\text { Multiple choice (multiple } \\
\text { answers permitted) }\end{array}$ & $\begin{array}{l}\text { Coastal areas } \\
\text { Wetlands } \\
\text { Water bodies, i.e., rivers, lakes } \\
\text { Arable land } \\
\text { Grazed land }\end{array}$ \\
\hline $\begin{array}{l}\text { Degree of integration of } \\
\text { CES in forest management }\end{array}$ & $\begin{array}{l}\text { To what extent are CES } \\
\text { integrated in the long-term } \\
\text { planning of the land/site(s), } \\
\text { which you manage? }\end{array}$ & $\begin{array}{l}\text { Multiple choice (one answer } \\
\text { permitted) }\end{array}$ & $\begin{array}{l}\text { Don't know } \\
\text { Not at all } \\
\text { Slightly } \\
\text { Significantly }\end{array}$ \\
\hline $\begin{array}{l}\text { Costs and barriers for further } \\
\text { CES implementation in } \\
\text { forest management }\end{array}$ & $\begin{array}{l}\text { Do any particular activities } \\
\text { represent an obstacle/ } \\
\text { challenge to the land/site(s), } \\
\text { which you manage? } \\
\text { Are there any costs linked to } \\
\text { the delivery/support of CES } \\
\text { on your land/site(s)? }\end{array}$ & Open-ended question ${ }^{\dagger}$ & $\begin{array}{l}\text { Costs related to the maintenance of facilities } \\
\text { Costs related to administrative and bureaucratic processes } \\
\text { Costs related to waste disposal } \\
\text { Obstacles related to the control of forest users } \\
\text { Obstacles related to the management of the land }\end{array}$ \\
\hline $\begin{array}{l}\text { Policy support for further } \\
\text { CES promotion in forest } \\
\text { management }\end{array}$ & $\begin{array}{l}\text { In which ways do you think } \\
\text { public authorities could help } \\
\text { land owners/managers to } \\
\text { deliver/support more? }\end{array}$ & Open-ended question $^{\dagger}$ & $\begin{array}{l}\text { Economic/financial direct or indirect support } \\
\text { Change in planning and management regulations } \\
\text { Education and training support } \\
\text { Relief in bureaucratic and administrative processes } \\
\text { Increase of public awareness and support for all forest } \\
\text { ecosystem services } \\
\text { Political support and public recognition } \\
\text { Support for facilities development and implementation }\end{array}$ \\
\hline
\end{tabular}

a high number of management actions was carried out, the most common being the maintenance of trails and paths within the forest (Fig. 1). We inquired about which facilities were present supporting CES. The most common facility were roads giving access to the property, followed by marked trails and paths within the property (Fig. 1). 
Fig. 1. Descriptive statistics of the respondents, their land, and management practices. CES = cultural ecosystem services.

\section{Country}

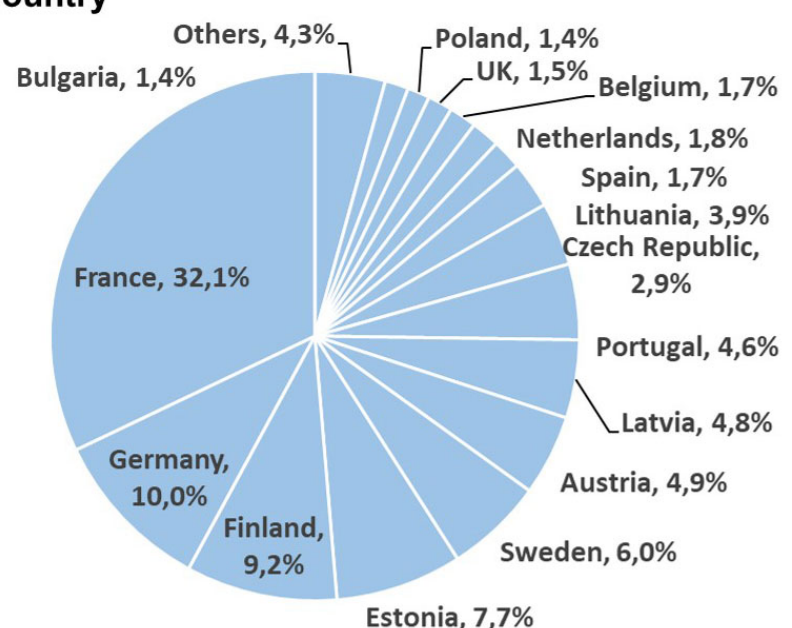

Estonia, 7,7\%
Age

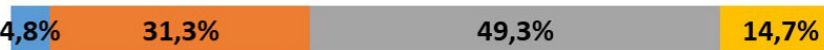

\section{Gender}

$17,80 \%$

Female Male

\section{Integration of CES in management plans}

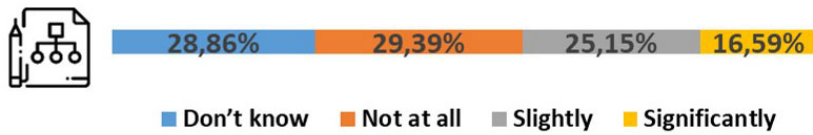

Management actions supporting CES
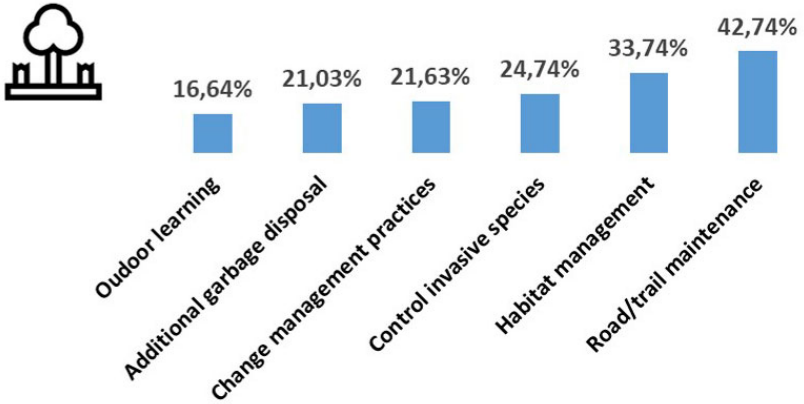

The respondents identified a large series of barriers for further fostering CES. The content of those answers was analyzed and grouped into different types of costs and obstacles. The identified types of costs were those related to the maintenance of facilities $(\mathrm{n}=237)$, those related to administrative and bureaucratic processes $(n=129)$, and those related to waste disposal $(n=92)$. In relation to the obstacles, we identified two main types: first, those obstacles related to the control of forest users, which mainly account for users' behavior-related problems, like littering, damaging of the forest, or access to restricted areas of the forest $(n=374)$; second, those obstacles related to the management of the land, which mainly accounts for problems related to balancing and reconciling multiple uses in the forest $(n=362)$.

In relation to the potential supporting mechanisms that would incentivize CES, the respondents identified several potential measures. These were grouped into different categories: economic/financial direct or indirect support $(n=168)$, change in planning and management regulations $(n=112)$, education and training support $(\mathrm{n}=55)$, relief in bureaucratic and administrative processes $(n=48)$, increase of public awareness and support for all forest ecosystem services $(n=47)$, political support and public recognition of forest and forest operators as stewards of sustainability ( $\mathrm{n}=39)$, and support for facilities development and implementation $(\mathrm{n}=33)$.

In relation to the CES present in European forests, the analysis showed a current wide range of CES (mean \pm SD: $5.8 \pm 3.3$ ). The most frequent CES was hunting, but there were seven other CES that appeared in more than $40 \%$ of the answers. These CES were research, wild products harvesting, farming, outdoor education, and sports (Fig. 2). 
Table 2. Factor loadings derived from the principal component analysis for current cultural ecosystem services (CES). For each variable, values in bold correspond to the factor for which the squared cosine is the largest.

\begin{tabular}{|c|c|c|c|c|c|}
\hline & $\begin{array}{c}\text { F1 - CES } \\
\text { simultaneity }\end{array}$ & $\begin{array}{l}\text { F2 - Focus } \\
\text { on hunting }\end{array}$ & $\begin{array}{l}\text { F3 - Focus } \\
\text { on farming }\end{array}$ & $\begin{array}{l}\text { F4 - Focus on } \\
\text { accomodation }\end{array}$ & $\begin{array}{l}\text { F5 - Focus } \\
\text { on fishing }\end{array}$ \\
\hline Beekeeping & 0.309 & 0.123 & 0.346 & 0.254 & -0.272 \\
\hline Hunting & 0.250 & 0.548 & 0.215 & -0.043 & -0.268 \\
\hline Recreational fishing & 0.044 & 0.118 & -0.701 & 0.040 & 0.509 \\
\hline Wild products harvesting & 0.476 & 0.332 & 0.147 & -0.234 & -0.223 \\
\hline Provision of area for accommodation & 0.464 & -0.161 & -0.110 & 0.558 & -0.121 \\
\hline Sports / Exercise & 0.662 & 0.201 & 0.002 & -0.034 & -0.076 \\
\hline Dog walking & 0.640 & 0.254 & -0.228 & 0.021 & 0.122 \\
\hline Horseback riding & 0.477 & 0.384 & -0.096 & 0.102 & 0.483 \\
\hline Bird / Nature watching & 0.637 & -0.145 & 0.046 & -0.127 & 0.094 \\
\hline Aesthetic experiences & 0.751 & -0.420 & 0.082 & -0.367 & 0.006 \\
\hline Artistic activities & 0.541 & -0.117 & -0.121 & 0.501 & -0.060 \\
\hline Spiritual enrichment & 0.530 & -0.135 & -0.274 & 0.036 & -0.063 \\
\hline Cultural / Historical sites & 0.610 & -0.097 & 0.287 & 0.244 & 0.059 \\
\hline Outdoor education & 0.768 & -0.392 & 0.058 & -0.349 & 0.013 \\
\hline Research & 0.217 & 0.313 & 0.015 & -0.180 & -0.417 \\
\hline Farming & 0.253 & 0.368 & 0.487 & -0.130 & 0.313 \\
\hline Eigenvalue & 4.292 & 1.344 & 1.173 & 1.080 & 1.014 \\
\hline Cumulative $\%$ & 26.825 & 35.223 & 42.554 & 49.303 & 55.644 \\
\hline
\end{tabular}

Fig. 2. Percentage of respondents indicating current and potential cultural ecosystem services (CES).

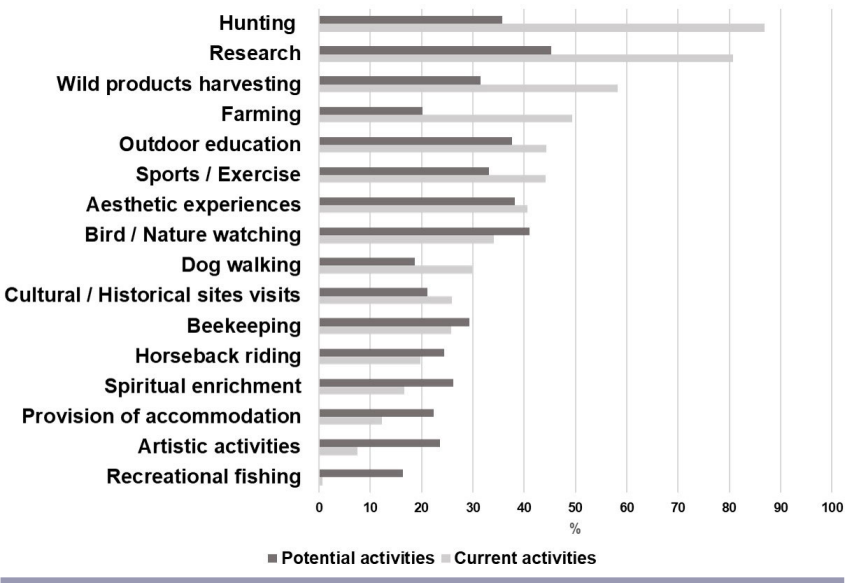

When asked which CES could be further supported if they were incentivized, the results showed that forest operators were rather open to a larger presence of CES (mean \pm SD: $4.6 \pm 4.4$ ). All the suggested CES in the survey were positively considered by at least $15 \%$ of the respondents (Fig. 2).

\section{Synergies and trade-offs between CES uses}

The PCA on CES present in the forest allowed the identification of five factors explaining the covariability in CES (Table 2). We selected the first five factors for the interpretation based on the eigenvalues (eigenvalue $>1$ ). For each factor, positive or negative values would indicate how each CES relate to each other, while higher or lower absolute values would indicate the relative importance of each CES in that factor. Based on these criteria, these five factors represented the following:

1. CES simultaneity (Table 2, F1): This factor showed many positive associations, differentiating those forests where multiple CES were simultaneously supplied from those forests with few or no CES. CES positively related to this factor included sports, dog walking, bird/nature watching, aesthetic experiences, and outdoor education.

2. Focus on hunting (Table 2, F2): This factor differentiated those forests where hunting played an important role from those where hunting did not take place. Hunting showed negative associations with CES like aesthetic experiences, outdoor recreation, and horseback riding.

3. Focus on farming (Table 2, F3): This factor indicated the role of farming in forests. Farming showed a strong negative association with recreational fishing.

4. Focus on accommodation (Table 2, F4): This factor indicated the relevance of providing area for accommodation in forests. It showed a positive association with artistic activities and a weak negative association with outdoor education and aesthetic experiences.

5. Focus on recreational fishing (Table 2, F5): This factor indicated the role of recreational fishing in forests. This CES showed a positive association with horseback riding and a negative association with research activities.

To assess attitudes and willingness toward further CES, we performed a PCA with all the presence/absence of all potential CES. Based on the factors' eigenvalues (eigenvalue $>1$ ), we selected two factors for interpretation (Table 3). Each of the factors represented the following:

1. Interest in diverse CES (Table 3, F1): This factor showed many positive associations, differentiating those forests where owners and managers would be willing to facilitate multiple CES from those forests with little or no wish for further CES

2. Interest in hunting (Table 3, F2): This factor differentiated those forests where hunting could take place in the future from those forests where hunting would not take place. Hunting showed negative associations with the majority of other CES. 
Table 3. Factor loadings derived from the principal component analysis for potential cultural ecosystem services (CES). For each variable, values in bold correspond to the factor for which the squared cosine is the largest.

\begin{tabular}{lcc}
\hline \hline & $\begin{array}{c}\text { F1 - Interest in } \\
\text { diverse CES }\end{array}$ & $\begin{array}{c}\text { F2 - Interest in } \\
\text { hunting }\end{array}$ \\
\hline Beekeeping & 0.583 & 0.273 \\
Hunting & 0.519 & $\mathbf{0 . 6 4 1}$ \\
Recreational fishing & 0.551 & 0.131 \\
Wild products harvesting & $\mathbf{0 . 6 4 5}$ & 0.339 \\
Provision of area for accommodation & 0.562 & -0.286 \\
Sports / Exercise & $\mathbf{0 . 6 9 0}$ & -0.036 \\
Dog walking & $\mathbf{0 . 6 7 8}$ & 0.142 \\
Horseback riding & $\mathbf{0 . 6 4 5}$ & 0.153 \\
Bird / Nature watching & $\mathbf{0 . 6 7 9}$ & -0.068 \\
Aesthetic experiences & $\mathbf{0 . 6 7 8}$ & -0.111 \\
Artistic activities & $\mathbf{0 . 6 7 0}$ & -0.438 \\
Spiritual enrichment & $\mathbf{0 . 6 5 0}$ & -0.379 \\
Cultural / Historical sites & 0.596 & -0.340 \\
Outdoor education & $\mathbf{0 . 6 6 8}$ & -0.247 \\
Research & $\mathbf{0 . 5 5 1}$ & 0.136 \\
Farming & 0.535 & 0.303 \\
Eigenvalue & 6.182 & 1.384 \\
Cumulative \% & 38.640 & 47.288 \\
\hline
\end{tabular}

\section{Grouping and characterizing forest owners and managers}

The HCA based on the factor loadings from the explanatory factors from the two PCAs classified forest operators into four main groups (Fig. 3A). Kruskal-Wallis tests showed that these groups significantly differed in the total number of CES in the forests they own/manage, willingness toward future CES, the amount and types of infrastructure and management actions in place supporting CES, and the number of different habitats present (Fig. 3B). We also assessed the potential influence of age or gender, but the analysis showed that they had no influence. Similarly, we assessed the potential influence of the country where the forest was located for the eight countries that concentrated most of the responses (Fig. 1). The results also showed that this factor did not have influence.

Based on this characterization, we can distinguish four main groups of European forest owners and managers (Fig. 3C):

- Group 1: those owning or managing forests with multiple CES, where further CES could potentially be promoted in the future.

- Group 2: in contrast to the first group, these people own or manage forests with few or no CES, and are not open to CES in the future.

- Group 3: those who, similarly to the first group, manage forests with multiple CES, but are not open to further CES in future.

- Group 4: those who manage forests with little or no current CES, but are open to CES in the future.

\section{DISCUSSION}

Current state of CES in European forests

Our survey shows a rather heterogeneous picture in relation to CES in Europe's forests, with a wide range of CES being harnessed, but also in relation to the facilities in place and management actions to support CES use. Europe's forests provide a high diversity of CES, with seven CES being present in more than $40 \%$ of the cases (hunting, wild products harvesting, research, farming, outdoor education, sports/exercise, and aesthetic experiences). Especially abundant are those CES that yield some material benefits and/or potential direct economic revenues. Among these CES, hunting stands out, but also wild products harvesting, beekeeping, or farming (although farming likely takes place in farmland patches within the property). Also relevant are those CES that comprehend important values in supporting local actors' personal attachment and cultural identity with the forests. Our study also highlights the important role that forests are taking as places for recreation, while showing the increasing importance of forest for knowledge production (education and research).

However, if the results show a rather high relevance of CES in European forestry, our data show that there is a considerable space for further promotion of CES, given the appropriate incentives and conditions. That is especially relevant for those CES where willingness for future implementation exceeds their current supply. These are bird/nature watching, beekeeping, horseback riding, spiritual enrichment, provision of area for accommodation, artistic activities, and recreational fishing. Most of these CES have in common that they require either making the forest more accessible to new users (bird/nature watching, spiritual enrichment) or specific knowledge that is not necessarily related to forestry activity (beekeeping, horseback riding, recreational fishing).

\section{Synergies and trade-offs between CES}

Our analysis allows us to discriminate forest owners and managers into two basic groups: those managing forests where multiple CES co-occur, and those with few or no CES (Table 2). We could therefore infer that CES tend to create positive associations among each other. These results are consistent with other studies that show that CES are the ES category that generate more synergistic associations (Howe et al. 2014, Andersson et al. 2015). These synergistic dynamics of CES should be capitalized on as part of policy instruments. Single policies that target one or a few CES have a high potential to additionally and simultaneously promote multifunctionality and diverse nonmaterial benefits in European forests.

Not all CES are fully complementary though, and we identified diverse trade-offs between CES. Although there is a bundle of CES that jointly appears in most CES interactions (Table 2: bird/ nature watching, aesthetic appreciation, artistic activities, spiritual enrichment, and outdoor recreation), this group of CES often enters into conflict with hunting, recreational fishing, farming, or the provision of accommodation. These CES all have in common the requirement for limited access of the public to some part of the land, which would then restricted permanently or temporarily for a single use by a small group of actors. These trade-off patterns were evident in the survey with multiple responses making a direct reference to the existing conflict between hunting and other CES, for example, "To me, because of the great movement of humans and animals (dogs), hunting and game keeping is totally impossible in many localities" (forest owner from Czech Republic, male, 25-30 years). Another clear example was, "Mushroom picking, jogging, orienteering, biking, 
Fig. 3. Types of forest owners and managers. (A) Dendrogram classifying forest owners and managers in four main groups based on their attitudes toward current cultural ecosystem services (CES). (B) Group comparisons (Kruskal-Wallis tests) between the different groups of forest owners and managers. For each variable, groups with significant different mean $(\mathrm{p}<0.05)$ have a different superscripted number. $(\mathrm{C})$ Characterization of the four groups of forest owners and managers.

\section{A Dendrogram - Groups of forest owners and managers}

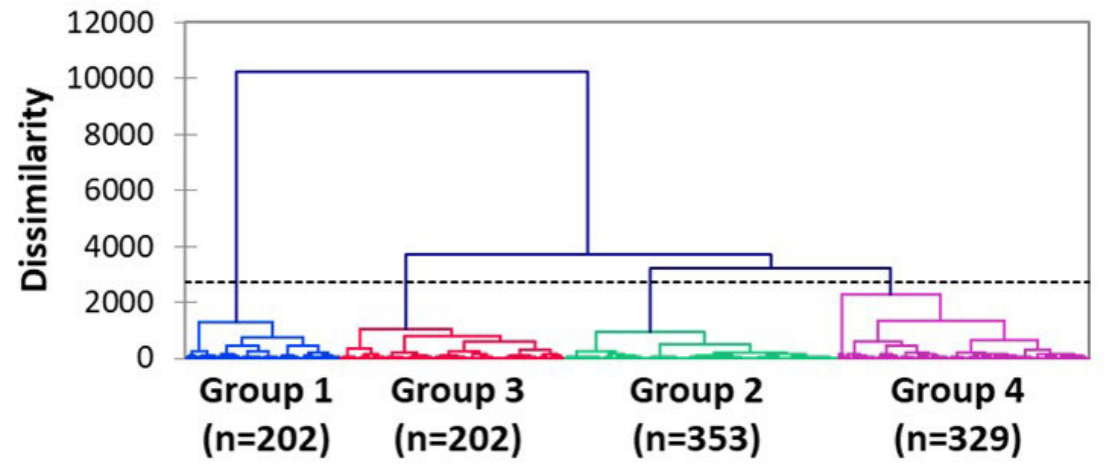

B Group-comparisons between the different groups of forest owners and managers

\begin{tabular}{lrrrc} 
& Group 1 & Group 2 & Group 3 & Group 4 \\
\hline $\begin{array}{l}\text { Current total number of CES } \\
\text { (K=669,46; } \boldsymbol{p}<0,01)\end{array}$ & $9,05^{1} \pm 3,25$ & $2,88^{2} \pm 1,41$ & $8,14^{1} \pm 2,42$ & $4,78^{3} \pm 2,15$ \\
\hline $\begin{array}{l}\text { Potential total number of CES } \\
\text { (K=825,02; } \boldsymbol{p}<0,01)\end{array}$ & $11,86^{1} \pm 2,96$ & $1,42^{2} \pm 1,55$ & $1,90^{2} \pm 2,13$ & $6,22^{3} \pm 3,26$ \\
\hline $\begin{array}{l}\text { Number of infrastructures and management action } \\
\text { (K=308,80; } \boldsymbol{p}<0,01)\end{array}$ & $6,52^{1} \pm 3,13$ & $2,49^{2} \pm 1,70$ & $5,21^{3} \pm 2,72$ & $4,05^{4} \pm 2,29$ \\
\hline $\begin{array}{l}\text { Number of habitats types in the property } \\
\text { (K=199,46; } \boldsymbol{p}<0,01)\end{array}$ & $2,70^{1} \pm 1,33$ & $1,09^{2} \pm 1,21$ & $2,19^{3} \pm 1,37$ & $1,63^{4} \pm 1,27$ \\
\hline
\end{tabular}

C Types of forest owners and managers

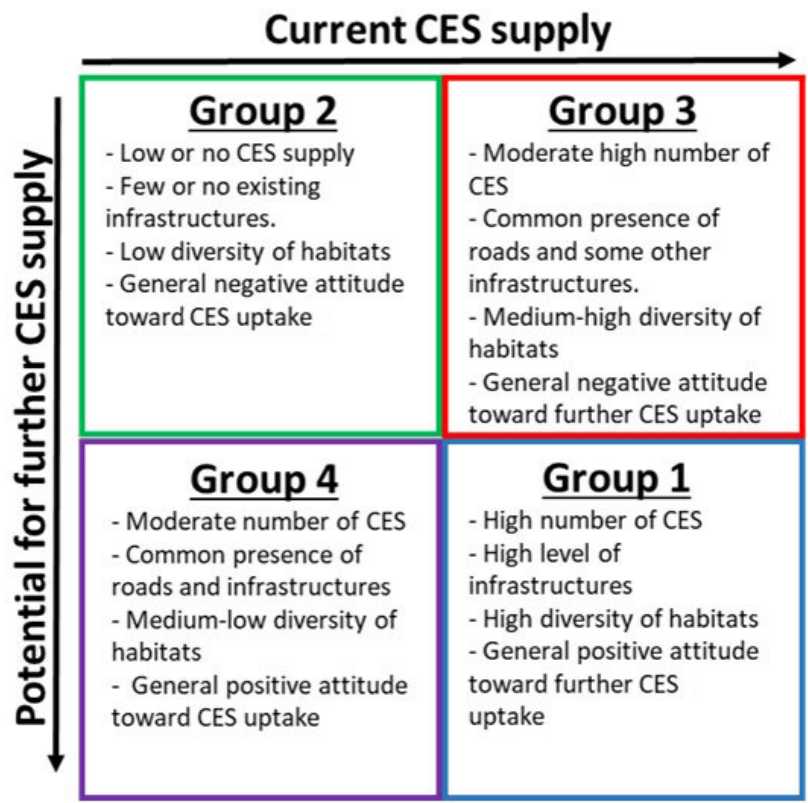


horse-back riding can enter into conflict with the hunting activities taking place on the estate. They also generally reduce the level of tranquility of wild game in the forest and can even cause them to increase the damage done to certain forestry infrastructure, i.e., forest fencing" (forest owner from UK, male, 51-60 years).

Our analysis of the obstacles and barriers perceived by forest operators suggest that these conflicts are not exclusive to those CES that limit free access to the forest, but are often extended to all forest ecosystem services that sometimes require similar exclusion of part of the land, i.e., timber production or biodiversity conservation. This is consistent with findings from previous studies (Joshi and Arano 2009, Hendee and Flint 2014), indicating that forest owners and managers implementing an active management of the forest (focused on timber extraction), have similar conflicts with CES. In our survey, this position was clearly stated in some answers, like, for example, "High visitor numbers, illegal parking, environmental pollution, make it impossible to correctly protect the working area. People are increasingly ignoring the barriers, an increasingly trespass without asking nor consent (horse riding, cycling geocaching, motor biking, model airplanes, drones, mass snowshoeing events (tourist events etc.)" (Forest owner from Austria, male, 41-50 years). These trade-offs indicate first, the need for transparent assessments on synergies and trade-offs among forest uses in Europe because not everything can be done at the same time (Tyrväinen et al. 2017). Second, in order to promote CES (and other forest ecosystem services), planning strategies should not only focus on forest operators, but also on the broader society and the way they engage with forests, especially in relation to recreation. Institutions have a large role to play in generating spaces and strategies that increase a common stewardship of the landscape (Enqvist et al. 2018), which allow a multifunctional management of the forests that satisfies the needs and motivations of the different types of users and beneficiaries of the forests.

\section{Engagement strategies for different types of forest owners and managers}

We identified four clearly differentiated groups of forest operators in relation to their attitudes toward CES (Fig. 3). These groups also differ in how diverse the habitats are within the property they own or manage, and how integrated CES are in their forest management. Their views on CES are likely not casual. As has been identified in previous studies, what forest operators decide relates to multiple individual motivations, often shared in communities (Bieling 2004, Hugosson and Ingemarson 2004, Steg et al. 2011, Sorice et al. 2014). Motivations driving management are related to context such as lifestyle and socioeconomic aspects (Joshi and Arano 2009, Howley 2013, Torralba et al. 2018).

Our data strongly suggests that CES are currently relevant for a significant proportion of European forest operators, but there are substantial differences among them. This current demand should be actively integrated into the European forest policy agenda to accommodate their different views and enhance a multifunctional management of the forest. However, we should also thoroughly explore what the consequences of CES use are, not only in relation to the trade-offs and synergies CES generate (among them and in relation to other forest ecosystem services), but also on how compatible CES are with different management models, and how they could be articulated with existing and potential viable business models. Our results hint at some challenges in relation to CES use and an active management of the forest, i.e. for timber extraction, but these results are not thorough enough to comprehensively understand them.

Considering this complexity, there is no blueprint or single strategy to promote CES uses in European forests. Europe's forests encompass a heterogeneous social-ecological landscape, where forests depart from very dissimilar situations in relation to current CES supply, and forest operators hold diverging motivations toward similar issues. These differences are not only transnational but exist at a local scale too. Therefore, policies should go beyond simplistic measures and offer a flexible policy framework. Such frameworks should take into account the local social-ecological context and be able to incorporate multiple instruments that satisfy the changing and mixed context-related needs of all those forest operators interested in CES in a given landscape.

As a consequence, we propose that, in order to promote CES effectively in management models that enhance multifunctionality, such policy frameworks could be based on four strategies, covering the diverse needs of the four main types of forest operators. Each strategy would need to be composed by locally agreed upon policy measures (Fig. 4):

1. Those forest operators departing from a negative situation, both in relation to current and future situations of CES, would require a strategy focused on stimulation, aiming to kick-start CES supply in the forest. Some mechanisms that would fit into this strategy would be, for example, seeking contracts and payments for ecosystem services/ compensation payments in contexts where societal demand for CES is high; or information programs highlighting the synergistic effects of CES with other forest ecosystem services. By providing economic incentives for CES, policy support would appeal to forest actors who initially are not interested in CES but are attracted to economic benefits and long-term sustainability of the forest (Bouwma et al. 2018). One example of such a strategy in Europe is the Finnish Landscape and Recreation Value Trade (LRVT), which compensates Finnish forest owners for the provision of landscape and recreational uses (Mäntymaa et al. 2018).

2. In cases where current CES are scarce but the general attitude toward CES is positive, strategies focused on facilitation, which would aid the implementation of management promoting CES would be appropriate. This would involve policy instruments such as the establishment of training and educational programs, or by lightening bureaucracy requirements. Examples of a demand for such strategies were made explicit in the survey, for example, "They could help (the authorities) by making planning instruments available, in general cutting red tape, support with contractual nature conservation, working on concepts that go beyond the farm, information, or educating target groups" (landowner from cluster four, male, 31-40 years, Austria). One example of such a strategy can be found in Estonia, where the Forestry Act actively supports investments aimed at increasing the economic, ecological, and social value of cultural heritage in forests (Bauer et al. 2004). 
Fig. 4. Different departing situations (A) would require different policy strategies (B) and policy mechanisms to promote cultural ecosystem services (CES) supply in European forests $(\mathrm{C})$.

\section{Different departing situations}

A

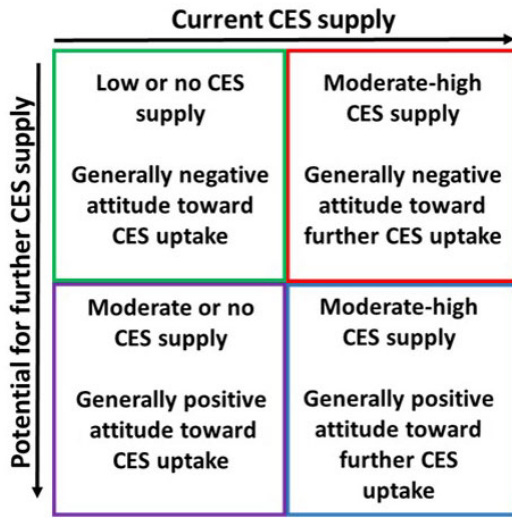

B

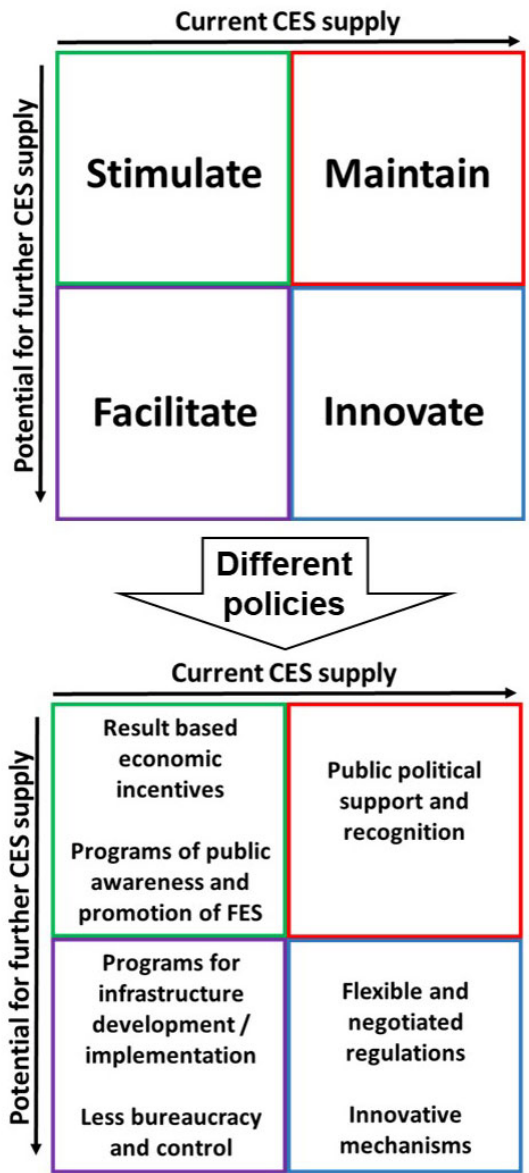

3. For those forests where current CES are high but where managers would not like to engage in more, the strategy should focus on securing and maintaining the current situation. Policy instruments should focus on increasing political support and promote public recognition. As it was stated in the questionnaire by a forest owner belonging to this type of forest owners, "We have been maintaining for generations without help from people. A little recognition and respect would be welcome" (landowner from cluster 3, male, $<30$ years, France). An example of this strategy would be the Austrian Forest Dialogue, an open dialogue process in which all forest stakeholders have the opportunity to define their forest and forestry interests (Hogl and Kvarda 2008).

4. Finally, there are cases of forest operators who, managing a forest with high relevance for CES, would like to positively engage more. This group would be the most appropriate for innovation strategies, with financial incentives to start up innovative management and business models, and where new regulations and scientific advances could be tested.

In that light, market-based approaches such as payments for ecosystem services might not always be the primary or best solution for promoting CES uses in forests. Rather, they should be integrated into policy-mix strategies. These strategies would complement precise spatially targeted market-based tools, with alternative and complementary strategies that reinforce the noneconomic value of CES. To find out what these strategies should specifically look like, our study suggests the need for fluid communication, where each of the actors present in the landscape feel heard and valued. This explicitly arose in the respondents' answers, with several calls for enhanced listening (i.e., "listen to forest owners' expectations...," forest owner from France, male, 41-50 years), recognition (i.e., "Explain to the public how much time it takes to manage our nature. And how fast you can destroy it," Swedish forest owner, male, 51-60 years), and dialogue (i.e., "It can only be consensual agreements after a frank dialogue. Everything is possible ... with respect for people, property, and therefore natural ecosystems," forest owner from France, male, 61-70 years).

Our review of CES-related policies in European countries, with a focus on the six most represented countries in the survey (France, Germany, Finland, Estonia, Sweden, and Austria) show that in general, there is much room for improvement in generating and combining these strategies (Appendix 1). With the exception of Estonia, which gives special emphasis to cultural heritage preservation, the only CES considered by most countries is outdoor recreation, and mostly to be controlled or regulated.

\section{Limitations of the study}

This study provides a snapshot of the current state of CES in European forests. Naturally, results could be improved by increasing the number of respondents in some of those countries where participation was relatively low. Furthermore, our data might be biased toward those forest operators particularly engaged and interested in promoting CES. In addition, some types of forest owners and managers might have been left out of the picture, especially those smallholders, who typically own a few hectares of forest but are not engaged in any kind of management. The effect of those factors could have been elicited by including 
in our survey questions related to the property size, land tenure, or to the economic benefits derived from each of the CES taking place in the property. Finally, we must assume that in the process of translating the survey into several languages, some specific terms, i.e. spirituality, historical, etc., might have been interpreted in different ways in different socio-cultural contexts. Therefore, we must underline the exploratory nature of the analysis presented in this publication, and emphasize the need for further research looking into the above-mentioned factors. However, our results consistently cover a wide range of views on forest management despite these potential biases. This allows us to conclude that the identified four major groups of forest owners and managers are consistently present in Europe. Future efforts should refine our approach and look in more depth at the local and regional relevance and distribution of these groups, and at context-related factors determining forest owners' and managers' decisions.

\section{CONCLUSIONS}

This study provides a first exploration of CES in European forests. Our data strongly suggests that CES are relevant for a significant proportion of European forest operators, but there are substantial differences among them. This heterogeneity should be actively integrated into the European forest policy agenda to accommodate their different views. However, we should also thoroughly explore what the consequences of CES are, not only in relation to the trade-offs and synergies CES generate (among them and in relation to other forest ecosystem services), but also how compatible CES are with different management models promoting multifunctionality, and how they could be articulated with existing and potential viable business models. Our results hint at some challenges in relation to CES and an active management of the forest, i.e. for timber extraction, but these results are not thorough enough to comprehensively understand them. The wide range of uses stated in our results challenge the concept of forests as a homogeneous land cover. A large proportion of respondents reported uses not typically associated with forestry, like farming, beekeeping, etc. These results suggest the need for policies and management models based on integrative landscape approaches that move forward from classic land cover classifications.

One major challenge would be to harmonize the general objective of promoting CES with the enormous diversity of local contexts. Given the (1) intrinsic heterogeneity of forests in Europe, with large gradients and stark contrasts in relation to landownership, property sizes, and contribution of forest outcomes in landowners' livelihoods; and (2) the diverged social, economic, and political trajectories that forest use had across Europe, the importance of considering local social-ecological contexts is crucial for having success in forests policies. Because of the multiplicity of actors playing a relevant role in CES uses in forests, it is highly recommended to implement, on the one hand, multiactor approaches that generate agreed upon and long-lasting solutions, and on the other hand, flexible policy frameworks that allow the use of multiple instruments and policies that satisfy heterogeneous needs.

Responses to this article can be read online at: http://www.ecologyandsociety.org/issues/responses. php/11587

\section{Acknowledgments:}

The authors acknowledge funding received from the European Community's H2020 Programme under grant agreement no. 773702 (project SINCERE).

\section{Data Availability Statement:}

The data that support the findings of this study are openly available in ZENODO at https://zenodo.org/record/3724451\#. Xs6xjMApBPZ, reference number md5:58e8517cb9f96edad19c8f6e4db1597c.

\section{LITERATURE CITED}

Addinsoft, S. 2009. XLSTAT software, version 9.0. Paris, France.

Andersson, E., M. Tengö, T. McPhearson, and P. Kremer. 2015. Cultural ecosystem services as a gateway for improving urban sustainability. Ecosystem Services 12:165-168. https://doi. org/10.1016/j.ecoser.2014.08.002

Bauer, J., M. Kniivilä, and F. Schmithüsen. 2004. Forest legislation in Europe: How 23 countries appproach the obligation to reforest, public access and use of non-wood forest products. Food and Agriculture Organization of the United Nations, Rome, Italy.

Bieling, C. 2004. Non-industrial private-forest owners: possibilities for increasing adoption of close-to-nature forest management. European Journal of Forest Research 123 (4):293-303. https://doi.org/10.1007/s10342-004-0042-6

Borrass, L., D. Kleinschmit, and G. Winkel. 2017. The "German model" of integrative multifunctional forest managementanalysing the emergence and political evolution of a forest management concept. Forest Policy and Economics 77:16-23. https://doi.org/10.1016/j.forpol.2016.06.028

Bouwma, I., C. Schleyer, E. Primmer, K. J. Winkler, P. Berry, J. Young, E. Carmen, J. Špulerová, P. Bezák, E. Preda, and A. Vadineanu. 2018. Adoption of the ecosystem services concept in EU policies. Ecosystem Services 29:213-222. https://doi. org/10.1016/j.ecoser.2017.02.014

Cáceres, D. M., E. Tapella, F. Quétier, and S. Díaz. 2015. The social value of biodiversity and ecosystem services from the perspectives of different social actors. Ecology and Society 20 (1):62. https://doi.org/10.5751/ES-07297-200162

Chan, K. M. A., P. Balvanera, K. Benessaiah, M. Chapman, S. Díaz, E. Gómez-Baggethun, R. Gould, N. Hannahs, K. Jax, S. Klain, et al. 2016. Why protect nature? Rethinking values and the environment. Proceedings of the National Academy of Sciences of the USA 113(6):1462-1465. https://doi.org/10.1073/pnas.1525002113

Chan, K. M. A., T. Satterfield, and J. Goldstein. 2012. Rethinking ecosystem services to better address and navigate cultural values. Ecological Economics 74:8-18. https://doi.org/10.1016/j. ecolecon.2011.11.011

Cooper, N., E. Brady, H. Steen, and R. Bryce. 2016. Aesthetic and spiritual values of ecosystems: recognising the ontological and axiological plurality of cultural ecosystem 'services.' Ecosystem Services 21:218-229. https://doi.org/10.1016/j.ecoser.2016.07.014

Duncker, P. S., K. Raulund-Rasmussen, P. Gundersen, K. Katzensteiner, J. De Jong, H. P. Ravn, M. Smith, O. Eckmüllner, 
and H. Spiecker. 2012. How forest management affects ecosystem services, including timber production and economic return: synergies and trade-offs. Ecology and Society 17(4):50. https://doi. org/10.5751/ES-05066-170450

Enqvist, J. P., S. West, V. A. Masterson, L. J. Haider, U. Svedin, and M. Tengö. 2018. Stewardship as a boundary object for sustainability research: linking care, knowledge and agency. Landscape and Urban Planning 179:17-37. https://doi. org/10.1016/j.landurbplan.2018.07.005

Estrada-Carmona, N., A. K. Hart, F. A. J. DeClerck, C. A. Harvey, and J. C. Milder. 2014. Integrated landscape management for agriculture, rural livelihoods, and ecosystem conservation: an assessment of experience from Latin America and the Caribbean. Landscape and Urban Planning 129:1-11. https://doi.org/10.1016/ j.landurbplan.2014.05.001

European Commission. 2006. Communication from the Commission to the Council and the European Parliament on an EU Forest Action Plan. (COM 2006/302 final). European Commission, Brussels, Belgium. [online] URL: https://eur-lex. europa.eu/legal-content/EN/TXT/?uri=LEGISSUM\%3A124277

European Commission. 2013. Regulation (EU) No 1305/2013 of the European Parliament and of the Council of 17 December 2013 on support for rural development by the European Agricultural Fund for Rural Development (EAFRD) and repealing Council Regulation (EC) No 1698/2005. European Commission, Brussels, Belgium. [online] URL: https://eur-lex.europa.eu/legal-content/ EN/TXT/?uri=celex\%3A32013R1305

Felipe-Lucia, M. R., S. Soliveres, C. Penone, P. Manning, F. van der Plas, S. Boch, D. Prati, C. Ammer, P. Schall, M. M. Gossner, J. Bauhus, F. Buscot, S. Blaser, N. Blüthgen, A. de Frutos, M. Ehbrecht, K. Frank, K. Goldmann, F. Hänsel, K. Jung, T. Kahl, T. Nauss, Y. Oelmann, R. Pena, A. Polle, S. Renner, M. Schloter, I. Schöning, M. Schrumpf, E.-D. Schulze, E. Solly, E. Sorkau, B. Stempfhuber, M. Tschapka, W. W. Weisser, T. Wubet, M. Fischer, and E. Allan. 2018. Multiple forest attributes underpin the supply of multiple ecosystem services. Nature Communications 9 (1):4839. https://doi.org/10.1038/s41467-018-07082-4

Gustafsson, L., M. Hannerz, M. Koivula, E. Shorohova, I. Vanha-Majamaa, and J. Weslien. 2020. Research on retention forestry in Northern Europe. Ecological Processes 9:3. https://doi. org/10.1186/s13717-019-0208-2

Hall, G. R. 1963. The myth and reality of multiple use forestry. Natural Resources Journal 3:276-290.

Hendee, J. T., and C. G. Flint. 2014. Incorporating cultural ecosystem services into forest management strategies for private landowners: an Illinois case study. Forest Science 60(6):1172-1179. https://doi.org/10.5849/forsci.13-710

Hill, R., G. Nates-Parra, J. J. G. Quezada-Euán, D. Buchori, G. LeBuhn, M. M. Maués, P. L. Pert, P. K. Kwapong, S. Saeed, S. J. Breslow, M. Carneiro da Cunha, L. V. Dicks, L. Galetto, M. Gikungu, B. G. Howlett, V. L. Imperatriz-Fonseca, P. O'B. Lyver, B. Martín-López, E. Oteros-Rozas, S. G. Potts, and M. Roué. 2019. Biocultural approaches to pollinator conservation. Nature Sustainability 2(3):214-222. https://doi.org/10.1038/s41893-019-0244$\underline{z}$
Hirsch, F., and F. J. Schmizhüsen. 2010. Private forest ownership in Europe. ETH, Zurich, Switzerland.

Hogl, K., and E. Kvarda. 2008. The Austrian forest dialogue: introducing a new mode of governance process to a well entrenched sectoral domain. InFER, University of Natural Resources and Applied Life Sciences, Vienna, Austria.

Hoogstra-Klein, M. A., V. Brukas, and I. Wallin. 2017. Multipleuse forestry as a boundary object: from a shared ideal to multiple realities. Land Use Policy 69:247-258. https://doi.org/10.1016/j. landusepol.2017.08.029

Howe, C., H. Suich, B. Vira, and G. M. Mace. 2014. Creating winwins from trade-offs? Ecosystem services for human well-being: a meta-analysis of ecosystem service trade-offs and synergies in the real world. Global Environmental Change 28:263-275. https:// doi.org/10.1016/j.gloenvcha.2014.07.005

Howley, P. 2013. Examining farm forest owners' forest management in Ireland: the role of economic, lifestyle and multifunctional ownership objectives. Journal of Environmental Management 123:105-112. https://doi.org/10.1016/j.jenvman.2013.03.013

Hugosson, M., and F. Ingemarson. 2004. Objectives and motivations of small-scale forest owners; theoretical modelling and qualitative assessment. Silva Fennica 38(2):430. https://doi. org/10.14214/sf.430

International Model Forest Network (IMFN). 2020. LatinAmerican model forest network. IMFN, Ottawa, Ontario, Canada. [online] URL: https://imfn.net/about/regional-networks/iberoamerican-model-forest-network/

Joshi, S., and K. G. Arano. 2009. Determinants of private forest management decisions: a study on West Virginia NIPF landowners. Forest Policy and Economics 11(2):118-125. https:// doi.org/10.1016/j.forpol.2008.10.005

Kanowski, P. J., and K. J. H. Williams. 2009. The reality of imagination: integrating the material and cultural values of old forests. Forest Ecology and Management 258(4):341-346. https:// doi.org/10.1016/j.foreco.2009.01.011

Kraus, D., and F. Krumm. 2013. Integrative approaches as an opportunity for the conservation of forest biodiversity. European Forest Institute, Joensuu, Finland.

Lazdinis, M., P. Angelstam, and H. Pülzl. 2019. Towards sustainable forest management in the European Union through polycentric forest governance and an integrated landscape approach. Landscape Ecology 34:1737-1749. https://doi. org/10.1007/s10980-019-00864-1

Maier, C., and G. Winkel. 2017. Implementing nature conservation through integrated forest management: a street-level bureaucracy perspective on the German public forest sector. Forest Policy and Economics 82:14-29. https://doi.org/10.1016/j. forpol.2016.12.015

Mäntymaa, E., A. Juutinen, L. Tyrväinen, J. Karhu, and M. Kurttila. 2018. Participation and compensation claims in voluntary forest landscape conservation: the case of the RukaKuusamo tourism area, Finland. Journal of Forest Economics 33:14-24. https://doi.org/10.1016/j.jfe.2018.09.003 
Millennium Ecosystem Assessment (MEA). 2005. Ecosystems and human well-being: synthesis. Island, Washington, D.C., USA.

Pascual, U., P. Balvanera, S. Díaz, G. Pataki, E. Roth, M. Stenseke, R. T. Watson, E. Başak Dessane, M. Islar, E. Kelemen, V. Maris, M. Quaas, S. M. Subramanian, H. Wittmer, A. Adlan, S. Ahn, Y. S. Al-Hafedh, E. Amankwah, S. T. Asah, P. Berry, A. Bilgin, S. J. Breslow, C. Bullock, D. Cáceres, H. Daly-Hassen, E. Figueroa, C. D. Golden, E. Gómez-Baggethun, D. GonzálezJiménez, J. Houdet, H. Keune, R. Kumar, K. Ma, P. H. May, A. Mead, P. O'Farrell, R. Pandit, W. Pengue, R. Pichis-Madruga, F. Popa, S. Preston, D. Pacheco-Balanza, H. Saarikoski, B. B. Strassburg, M. van den Belt, M. Verma, F. Wickson, and N. Yagi. 2017. Valuing nature's contributions to people: the IPBES approach. Current Opinion in Environmental Sustainability 26-27:7-16. https://doi.org/10.1016/j.cosust.2016.12.006

Pistorius, T., H. Schaich, G. Winkel, T. Plieninger, C. Bieling, W. Konold, and K.-R. Volz. 2012. Lessons for REDDplus: a comparative analysis of the German discourse on forest functions and the global ecosystem services debate. Forest Policy and Economics 18:4-12. https://doi.org/10.1016/j.forpol.2011.09.001

Plieninger, T., T. Kizos, C. Bieling, L. Le Dû-Blayo, M.-A. Budniok, M. Bürgi, C. L. Crumley, G. Girod, P. Howard, J. Kolen, T. Kuemmerle, G. Milcinski, H. Palang, K. Trommler, and P. H. Verburg. 2015. Exploring ecosystem-change and society through a landscape lens: recent progress in European landscape research. Ecology and Society 20(2):5. https://doi.org/10.5751/ES-07443-200205

Porter-Bolland, L., E. A. Ellis, M. R. Guariguata, I. Ruiz-Mallén, S. Negrete-Yankelevich, and V. Reyes-García. 2012. Community managed forests and forest protected areas: an assessment of their conservation effectiveness across the tropics. Forest Ecology and Management 268:6-17. https://doi.org/10.1016/j.foreco.2011.05.034

Pulla, P., A. Schuck, P. J. Verkerk, B. Lasserre, M. Marchetti, and T. Green. 2013. Mapping the distribution of forest ownership in Europe. European Forest Institute, Joensuu, Finland.

Rendenieks, Z., O. Nikodemus, and G. Brümelis. 2015. The implications of stand composition, age and spatial patterns of forest regions with different ownership type for management optimisation in northern Latvia. Forest Ecology and Management 335:216-224. https://doi.org/10.1016/j.foreco.2014.10.001

Satz, D., R. K. Gould, K. M. A. Chan, A. Guerry, B. Norton, T. Satterfield, B. S. Halpern, J. Levine, U. Woodside, N. Hannahs, X. Basurto, and S. Klain. 2013. The challenges of incorporating cultural ecosystem services into environmental assessment. Ambio 42(6):675-684. https://doi.org/10.1007/s13280-013-0386-6

Schaich, H., and T. Plieninger. 2013. Land ownership drives stand structure and carbon storage of deciduous temperate forests. Forest Ecology and Management 305:146-157. https://doi. org/10.1016/j.foreco.2013.05.013

Schleyer, C., C. Görg, J. Hauck, and K. J. Winkler. 2015. Opportunities and challenges for mainstreaming the ecosystem services concept in the multi-level policy-making within the EU. Ecosystem Services 16:174-181. https://doi.org/10.1016/j. ecoser.2015.10.014
Scott, J. C. 1998. Seeing like a state: how certain schemes to improve the human condition have failed. Yale University Press, New Haven, Connecticut, USA. https://doi.org/10.2307/j.ctvxkn7ds

Sorice, M. G., U. P. Kreuter, B. P. Wilcox, and W. E. Fox III. 2014. Changing landowners, changing ecosystem? Land-ownership motivations as drivers of land management practices. Journal of Environmental Management 133:144-152. https://doi.org/10.1016/ j.jenvman.2013.11.029

Sotirov, M., and B. Arts. 2018. Integrated forest governance in Europe: an introduction to the special issue on forest policy integration and integrated forest management. Land Use Policy 79:960-967. https://doi.org/10.1016/j.landusepol.2018.03.042

Steg, L., J. I. M. De Groot, L. Dreijerink, W. Abrahamse, and F. Siero. 2011. General antecedents of personal norms, policy acceptability, and intentions: the role of values, worldviews, and environmental concern. Society \& Natural Resources 24 (4):349-367. https://doi.org/10.1080/08941920903214116

Torralba, M., N. Fagerholm, T. Hartel, G. Moreno, and T. Plieninger. 2018. A social-ecological analysis of ecosystem services supply and trade-offs in European wood-pastures. Science Advances 4(5):eaar2176. https://doi.org/10.1126/sciadv. $\underline{\operatorname{aar} 2176}$

Turnpenny, J., D. Russel, and A. Jordan. 2014. The challenge of embedding an ecosystem services approach: patterns of knowledge utilisation in public policy appraisal. Environment and Planning C: Government and Policy 32(2):247-262. https://doi. org/10.1068/c1317j

Tyrväinen, L., T. Plieninger, and G. Sanesi. 2017. How does the forest-based bioeconomy relate to amenity values? Pages 92-100 in G. Winkel, editor. Towards a sustainable European forest-based bioeconomy - assessment and the way forward. What science can tell us. European Forest Institute, Joensuu, Finland.

Urquhart, J., P. Courtney, and B. Slee. 2012. Private woodland owners' perspectives on multifunctionality in English woodlands. Journal of Rural Studies 28(1):95-106. https://doi.org/10.1016/j. jrurstud.2011.08.006

Von Carlowitz, H. 1732. Sylvicultura Oeconomica: Hausswirthliche Nachricht und Naturmäßige Anweisung zur Wilden Baum-Zucht. Johann Friedrich Braun, Leipzig, Germany.

Ward, Jr., J. H. 1963. Hierarchical grouping to optimize an objective function. Journal of the American Statistical Association 58(301):236-244. https://doi.org/10.1080/01621459.1963.10500845

Winkel, G. 2012. Foucault in the forests - a review of the use of 'Foucauldian' concepts in forest policy analysis. Forest Policy and Economics 16:81-92. https://doi.org/10.1016/j.forpol.2010.11.009

Winkel, G., and M. Sotirov. 2016. Whose integration is this? European forest policy between the gospel of coordination, institutional competition, and a new spirit of integration. Environment and Planning C: Government and Policy 34 (3):496-514. https://doi.org/10.1068/c1356j

Wolff, S., C. J. E. Schulp, and P. H. Verburg. 2015. Mapping ecosystem services demand: a review of current research and 
future perspectives. Ecological Indicators 55:159-171. https://doi. org/10.1016/j.ecolind.2015.03.016

Wunder, S., S. Feder, D. Pettenella, G. Bottaro, and M. Torralba. 2019. DELIVERABLE 1.4 "What works?" State-of-the-art synthesis report about best-practice design and implementation of PES and other IM in the European context. H2020 project no.773702 RUR-05-2017. European Commission, Brussels, Belgium. [online] URL: https://sincereforests.eu/wp-content/ uploads/2020/04/D1.4.pdf 
Appendix 1. CES-related policies in France, Germany, Finland, Estonia, Sweden, and Austria.

\begin{tabular}{|c|c|c|c|c|c|c|c|}
\hline & & France & Germany & Finland & Estonia & Sweden & Austria \\
\hline 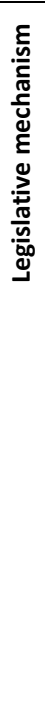 & $\begin{array}{l}\text { Access, recreation \& } \\
\text { Tourism }\end{array}$ & $\begin{array}{l}\text { The forest law grants open } \\
\text { access to state and municipal / } \\
\text { communal forests. Private } \\
\text { forest owners can forbid the } \\
\text { access to their forests and can } \\
\text { conclude contracts with public } \\
\text { authorities on opening its } \\
\text { forest to visitors. The public } \\
\text { authority will then bear all } \\
\text { costs (Bauer et al 2004). }\end{array}$ & $\begin{array}{l}\text { Federal Forest Act (2017) } \\
\text { legally guarantees that } \\
\text { anyone can enter forests for } \\
\text { recreational purposes at any } \\
\text { time } \\
\text { Federal Nature } \\
\text { Conservation Act (2019): } \\
\text { nature and landscape should } \\
\text { be protected for, inter alia } \\
\text { their recreational value. } \\
\text { "...suitable areas for } \\
\text { recreational purposes, in } \\
\text { terms of their properties and } \\
\text { location, are to be protected } \\
\text { and kept or rendered } \\
\text { accessible." }\end{array}$ & $\begin{array}{l}\text { Open public access to forests, } \\
\text { although the Forest Act does not } \\
\text { include specific regulations. The } \\
\text { According to the Finnish } \\
\text { Environmental Administration: } \\
\text { "Everybody has right to roam } \\
\text { freely in the } \\
\text { forests, no matter who owns the } \\
\text { land, and the right of way may be } \\
\text { limited only by official prohibition } \\
\text { enforced by the public } \\
\text { authorities." } \\
\text { (Bauer et al 2004). } \\
\text { Only country assessed with } \\
\text { legislation directly dedicated to } \\
\text { recreation: Finnish Outdoor } \\
\text { Recreation Act (1973). Contains } \\
\text { regulations regarding outdoor } \\
\text { recreational routes and camping } \\
\text { sites. }\end{array}$ & $\begin{array}{l}\text { Open access to forests. "If forests } \\
\text { are owned by persons in public law } \\
\text { or they are privately owned, but not } \\
\text { fenced or marked, (...) it is } \\
\text { permitted to stay in the forest if no } \\
\text { disturbance is caused, if the interest } \\
\text { of the owner is } \\
\text { not harmed and if his requirements } \\
\text { are followed "(Forest Act of Estonia } \\
\text { (2014)). The Act allows for the } \\
\text { owner to suspend the right to } \\
\text { access in some cases (Bauer et al } \\
\text { 2004). }\end{array}$ & $\begin{array}{l}\text { Swedish Forestry Act (2010): no } \\
\text { specific reference to recreation } \\
\text { and CES per se, but has a strong } \\
\text { emphasis on cultural heritage. In } \\
\text { comparison to other forests acts, } \\
\text { more specific regulations } \\
\text { impacting forest management to } \\
\text { preserve cultural heritage } \\
\text { Open public access to forests is } \\
\text { common law. Although the } \\
\text { Forest Act does not refer to this } \\
\text { right, other laws (the } \\
\text { Environmental Law and the Penal } \\
\text { Code) have some provisions } \\
\text { relating to it (Øian et al 2018). }\end{array}$ & $\begin{array}{l}\text { Austrian Forest Act } \\
\text { (2016): recognizes the } \\
\text { social function of forests. } \\
\text { Guarantees open access } \\
\text { to public for recreational } \\
\text { purposes, may be subject } \\
\text { to certain } \\
\text { restrictions. } \\
\text { "Access may be regulated } \\
\text { or restricted for specific } \\
\text { uses and/or may require } \\
\text { the consent of the land } \\
\text { Owner" Bauer et al 2004) }\end{array}$ \\
\hline & $\begin{array}{l}\text { Specific recreational } \\
\text { activities }\end{array}$ & & $\begin{array}{l}\text { The Federal Forests Act } \\
\text { allows cycling in horseback } \\
\text { riding in the forests, } \\
\text { provided that one keeps to } \\
\text { the forest paths. }\end{array}$ & $\begin{array}{l}\text { Camping (temporarily) is allowed, } \\
\text { if no damaged is caused Walking, } \\
\text { skiing, cycling, horse riding is } \\
\text { allowed on another's property, } \\
\text { but not crossing with a motorized } \\
\text { vehicle. (Øian et al 2018; Bauer et } \\
\text { al 2004). }\end{array}$ & $\begin{array}{l}\text { "Camping and } \\
\text { making a fire is permitted only at } \\
\text { designated places and with the } \\
\text { permission of the owner" } \\
\text { (Bauer et al 2004). }\end{array}$ & $\begin{array}{l}\text { Temporarily camping, lighting a } \\
\text { campfire, walking, skiing, cycling } \\
\text { or riding is allowed, should no } \\
\text { damage be caused through } \\
\text { reasonable care. There is } \\
\text { currently a debate on whether } \\
\text { the owner's permission should be } \\
\text { required for horse-riding. } \\
\text { (Bauer et al 2004). }\end{array}$ & $\begin{array}{l}\text { "Camping, driving or } \\
\text { riding vehicles, or horse- } \\
\text { riding are only } \\
\text { permissible with the } \\
\text { consent of the forest } \\
\text { owner, and the use of } \\
\text { forest roads requires } \\
\text { permission of the } \\
\text { institution or person } \\
\text { responsible for } \\
\text { maintenance." Skiing is } \\
\text { only allowed on marked } \\
\text { trails/special ski routes. } \\
\text { Consent from the owner } \\
\text { is required for cross- } \\
\text { country skiing without } \\
\text { marked courses (Bauer et } \\
\text { al 2004). }\end{array}$ \\
\hline
\end{tabular}




\begin{tabular}{|c|c|c|c|c|c|c|c|}
\hline & $\begin{array}{l}\text { Harvesting wild } \\
\text { products }\end{array}$ & $\begin{array}{l}\text { Forestry Code (1979): } \\
\text { "collection of forest goods in } \\
\text { private forests is } \\
\text { forbidden. Such goods belong } \\
\text { to the owner and his } \\
\text { permission is needed for } \\
\text { collecting." (Bauer et al 2004) }\end{array}$ & $\begin{array}{l}\text { The German Federal Forest } \\
\text { Act does not refer to } \\
\text { harvesting of wild products. } \\
\text { Federal Nature } \\
\text { Conservation Act } \\
\text { determines that it is } \\
\text { prohibited to collect } \\
\text { endangered plants or } \\
\text { animals. It is common law } \\
\text { that part of the right to } \\
\text { access the forest, collection } \\
\text { of wild products for } \\
\text { personal use is included. } \\
\text { Specific regulations are } \\
\text { made at sub-national } \\
\text { governance level } \\
\text { (Bauer et al 2004; Bösch et al } \\
\text { 2018). }\end{array}$ & $\begin{array}{l}\text { Everybody is allowed to harvest } \\
\text { wild products (berries, } \\
\text { mushrooms, flowers, dry twigs } \\
\text { and branches, } \\
\text { cones and nuts as per the Penal } \\
\text { Code) Mosses and lichen are } \\
\text { prohibited from harvesting. "In } \\
\text { Lapland, the Ministry of } \\
\text { Agriculture and Forestry may deny } \\
\text { to non-local people gathering on } \\
\text { state owned land if the collection } \\
\text { of berries and other NWFP is } \\
\text { significant importance } \\
\text { for local people's livelihood" } \\
\text { (Bauer et al 2004) }\end{array}$ & $\begin{array}{l}\text { Forest Act of Estonia: Harvesting of } \\
\text { wild products (berries, mushrooms, } \\
\text { nuts, herbs and ornamental } \\
\text { branches) is allowed in forests } \\
\text { owned by persons in public law and } \\
\text { in private forests that are not } \\
\text { fenced or marked, under certain } \\
\text { conditions (Øian et al 2018) }\end{array}$ & $\begin{array}{l}\text { "The right of free access allows } \\
\text { everybody to pick berries, } \\
\text { mushrooms and flowers" (Bauer } \\
\text { et al 2004). }\end{array}$ & $\begin{array}{l}\text { Wild products belong to } \\
\text { the landowner. The } \\
\text { Austrian Forest Act: } \\
\text { Harvesting of wild } \\
\text { products (fruits, seeds, } \\
\text { mushrooms, twigs, earth, } \\
\text { turf) is only permissible in } \\
\text { small quantities. } \\
\text { Collection for commercial } \\
\text { purposes without prior } \\
\text { permission is an } \\
\text { administrative offence } \\
\text { (Bauer et al 2004). } \\
\text { The owner may prohibit } \\
\text { harvesting of wild } \\
\text { mushrooms through } \\
\text { signposts or fencing } \\
\text { (Prokofieva et al 2016) }\end{array}$ \\
\hline 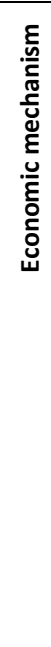 & Tax / subsidies & - & 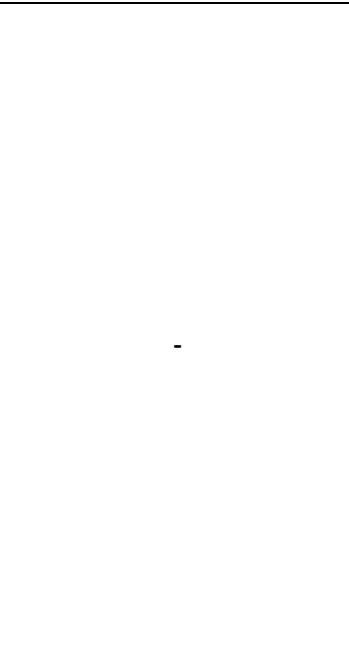 & - & $\begin{array}{l}\text { "If the owner has incurred } \\
\text { expenses for increasing the } \\
\text { productivity of NWFP, he has the } \\
\text { right to charge a fee for the } \\
\text { gathering of products by third } \\
\text { parties" } \\
\text { (Bauer et al 2004). } \\
\text { Forestry Act: Support to private } \\
\text { forestry } \\
\text { "The state supports [inter alia] the } \\
\text { investments aimed at increasing the } \\
\text { economic, ecological, social and } \\
\text { cultural value of the forest and the } \\
\text { silviculture work performed by } \\
\text { private forest owners, including the } \\
\text { preservation of cultural heritage } \\
\text { and key habitats, and the work } \\
\text { aimed at forest improvement". }\end{array}$ & - & 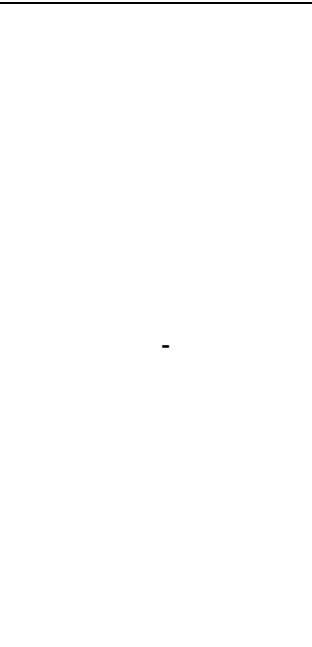 \\
\hline
\end{tabular}




\begin{tabular}{|c|c|c|c|c|c|c|c|}
\hline & License \& permits & $\begin{array}{l}\text { Commercial activities based on } \\
\text { exploitation of non-wood forest } \\
\text { products require a permission } \\
\text { of the forest } \\
\text { owner. Some forest owners } \\
\text { (private and state) may } \\
\text { organise a system of } \\
\text { commercial licensing in } \\
\text { particular } \\
\text { in the case of eatable } \\
\text { mushrooms or for certain small } \\
\text { forest fruits such as } \\
\text { blueberries. The same holds for } \\
\text { fishing in forested areas. The } \\
\text { owner may organise a system } \\
\text { of issuing commercial permits }\end{array}$ & $\begin{array}{l}\text { Hunting and fishing licenses } \\
\text { are required. } \\
\text { In Nordrhein-Westfalen } \\
\text { permits are required for } \\
\text { horse-riding in the forest. }\end{array}$ & $\begin{array}{l}\text { A permit for motorised vehicles, } \\
\text { (such as snowmobiles) is required. }\end{array}$ & - & - & $\begin{array}{l}\text { Permits for horse-riding } \\
\text { and cross-country skiing is } \\
\text { required. Hunting and } \\
\text { fishing licenses are } \\
\text { required. }\end{array}$ \\
\hline & PES schemes & 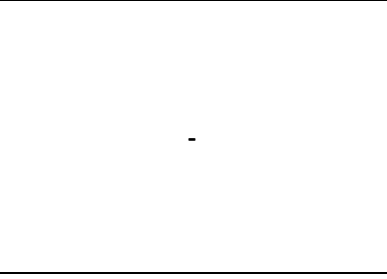 & - & $\begin{array}{l}\text { Finnish Landscape and Recreation } \\
\text { Value Trade (LRVT) is a PES } \\
\text { scheme where "forest owners } \\
\text { would be compensated for } \\
\text { voluntarily enhancing the } \\
\text { provision of landscape and } \\
\text { recreational cause in their own } \\
\text { forests" (Mäntymaa et al) }\end{array}$ & - & - & - \\
\hline 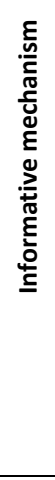 & $\begin{array}{l}\text { Education/ training/ } \\
\text { public } \\
\text { acknowledgement }\end{array}$ & - & - & $\begin{array}{l}\text { "Finnish government actively } \\
\text { supports and promotes the } \\
\text { concept of Jokamiehenoikeus } \\
\text { [public right to open access] by } \\
\text { publishing the rules, including } \\
\text { those that are not codified" (Øian } \\
\text { et al 2018) }\end{array}$ & & & $\begin{array}{l}\text { Austrian Forest Dialogue: } \\
\text { Is a open, continuous } \\
\text { dialogue process in which } \\
\text { all forest stakeholders } \\
\text { (and anyone who has an } \\
\text { economic or cultural } \\
\text { interest) have the } \\
\text { opportunity to define } \\
\text { their forest and forestry } \\
\text { interests. Using forests for } \\
\text { recreational and cultural } \\
\text { purposes (including } \\
\text { tourism) is often one of } \\
\text { the discussion points. }\end{array}$ \\
\hline
\end{tabular}




\section{$\underline{\text { References: }}$}

Legislation:

Austria Federal Forest Act, (2016). (as amended) [Gesamte Rechtsvorschrift für Forstgesetz 1975]. (retrieved 17.01.2020)

https://www.ris.bka.gv.at/GeltendeFassung.wxe?Abfrage=Bundesnormen\&Gesetzesnummer=10010371

Estonia Forest Act (2014). (as amened) [Metsaseadus 2007] (retrieved 17.01.2020) [https://www.riigiteataja.ee/en/eli/510022014001/consolide]

Finnish Outdoor Recreation Act (1973). [Ulkoilulaki 1973] (retrieved on 17.10.2020) [https://www.finlex.fi/en/laki/kaannokset/1973/en19730606.pdf]

German Federal Nature Conservation Act (2019). (as amended) [Gesetz über Naturschutz und Landschaftspflege (Bundesnaturschutzgesetz) 2009]. (retrieved 17.01.2020) http://www.gesetze-im-internet.de/bnatschg_2009/BNatSchG.pdf

German Federal Forest Act (2017). (as amended) [Gesetz zur Erhaltung des Waldes und zur Förderung der Forstwirtschaft (Bundeswaldgesetz) 1975]. (retrieved 17.01.2020) https://www.gesetze-im-internet.de/bwaldg/BWaldG.pdf

Swedish Forest Act (2010). (as amended) [Skogslag 1996]. (retrieved 17.01.2020) [http://finlex.fi/sv/laki/ajantasa/1996/19961093]

Academic literature:

Bauer, J., Kniivilä, M., and Schmithüsen, F. (2004) Geneva Timber and Forest Discussion Paper 3 - Forest Legislation in Europe: How 23 Countries Appproach the obligation to reforest, public access and use of non-wood forest products. As study implemented in the framework of the European Forest Sector Outlook Study (EFSOS), United Nations, Geneva Switzerland

Bösch, M., Elsasser, P., Franz, K., Schneider, H., Lorenz, M., Moning, C., Olschewski, R., Roedl, A., Schröppel, B. \& Weller P. (2018). Forest Ecosystem Services in rural areas of Germany - insights from the national TEEB study. Ecosystem Services, 31(Part A), 77-83. DOI: 10.1016/j.ecoser.2018.03.014.

Lazdinis, M., Angelstam, P. and Pülzl, H. (2019). Towards sustainable forest management in the Euopean Union through polycentric forest governance and an integrated landscape approach. Lanscape Ecol, 34 (1737-1749)

Mäntymaa, E.; Juutinen, A.; Tyrväinen, L.; Karhu, J.; Kurttila, M. (2018). Participation and compensation claims in voluntary forest landscape conservation: The case of the RukaKuusamo tourism area, Finland. J. For. Econ., 33 (14-24)

Øian, H, Fredman, P., Sandell, K., Sæpórsdóttir, A.D., Tyrväinen, L. and Jensen, F.S. (2018). Tourism, nature and sustainability: A review of policy instruments in the Nordic countries. Nordic Counsel of Ministers, Denmark

Prokofieva, I., Górriz-Mifsud, E., J-A Bonet, J-A. and de Aragón, J.M. (2017). Viability of Introducing Payments for the Collection of Wild Forest Mushrooms in Catalonia (NorthEast Spain) Small-scale Forestry, 16 (147-167) 
Appendix 2. Questionnaire.

1. Please describe the types of habitats/features present on the land which you manage. Indicate all options that apply:

- Forests/Woodlands

- Farmland (grasslands)

- Farmland (arable land)

- Mountain/upland areas

- Wetlands

- Water bodies (e.g. rivers/lakes)

- Coastal areas

Other (please describe):

2. Which of these activities currently take place on the land/site(s) you manage? Indicate all options that apply:

Beekeeping

Hunting

Recreational fishing

Wild products harvesting

Provision of area for accommodation

Sports / Exercise

Dog walking

Horseback riding

Bird / Nature watching

Aesthetic experiences

Artistic activities

Spiritual enrichment

Cultural / Historical sites

Outdoor education

Research

Farming

Other (please explain):

3. Could the site/area that you manage deliver more CES activities (that provide nonmaterial benefits to people, such as positive aesthetic or recreational experiences) if you received additional incentives (e.g. financial, improved recognition or otherwise)? Indicate all options that apply:

Beekeeping

○ Hunting

- Recreational fishing

- Wild products harvesting

Provision of area for accommodation

- Sports / Exercise

Dog walking

Horseback riding

Bird / Nature watching

Aesthetic experiences

Artistic activities

Spiritual enrichment

Cultural / Historical sites

Outdoor education

Research

Farming

Other (please explain): 
4. What infrastructure is in place to provide access to the land/site(s)? Indicate all options that apply:

- Road (including forest road)

○ Parking

- Toilets

- Walkways/bridges

- Trails (e.g. hiking, mountain biking, horse riding)

- Signage

Other (please explain):

5. To what extent are CES integrated in the long-term planning of the land/site(s) which you manage? Indicate only one option:

- Significantly

- Slightly

- Not at all

- Don't know

5.1 If slightly/significantly, please describe which CES are most relevant to your land/site(s):

6. Do any particular activities represent an obstacle/challenge to the land/site(s) which you own/manage?

- Yes

O No

If yes, please describe the particular obstacle/challenge:

7. What types of actions do you put in place to support CES on your land/site(s)?

- Habitat management

- Control of invasive alien species

- Changing land management practices

Road/trail maintenance

Additional garbage collection/disposal

Outdoor learning/education

Installation of information signs

Parking

- I take no action

Other (please explain):

8. Do you derive financial benefit from CES (e.g. from usage fees, funding) on the land/site you manage?

O Yes

- No

8.1 If yes, please describe the types of benefits.

9. Do you think public authorities could help land owners/managers to deliver/support more CES?

o Yes

o No

9.1 If yes, please describe how.

10. Are there any costs linked to the delivery/support of CES on your land/site(s)? *

- Yes

- No

10.1 If yes, please describe the types of costs.

11. Country

12. Age

13. Gender 